\title{
CLINICAL AND HISTOPATHOLOGICAL STUDY OF CALCINEURIN INHIBITORS INDUCED GINGIVAL HYPERPLASIA AFTER KIDNEY TRANSPLANT
}

\author{
Hend H El-Kateb*, Omar H Khashaba ${ }^{* *}$, Fagr B Bazeed ${ }^{* * *}$, Ahmed F Donia****, \\ Mohammad H El-Nablaway ${ }^{* * * * *}$ and Rehab Rizk EL- Zehary ${ }^{* * * * * *}$
}

\begin{abstract}
Objective: Perform clinical and histopathological evaluations of gingival hyperplasia after kidney transplantation in patients receiving either cyclosporine (CsA) or tacrolimus (TAC).

Subjects and Methods: A sample of 54 male renal transplant patients who have undergone immunosuppressive regimen $(\mathrm{CsA}=28$ and $\mathrm{TAC}=26)$ were examined in respect to demographic, pharmacologic and periodontal variables. Gingival overgrowth (GO) was assessed by using gingival enlargement index. In addition gingival biopsies were examined histopathologically with Hematoxylin and eosin (H\&E) stain and Immunohistochemistry using caspase 3 expression and histomorphometric Analyses. Furthermore the serum level of matrix metalloproteinase (MMP2) was assessed in the two groups. Data were analyzed statistically using the Statistical Package for Social Sciences (SPSS).
\end{abstract}

Results: Considering gingival enlargement, there was a statistically significant difference between (CsA) and (TAC) group's index with higher mean in (CsA) group versus (TAC) group. Considering the gingival bleeding index, there was a statistically significant difference between (CsA) and (TAC) groups with higher mean in (CsA) group versus (TAC) group and regarding serum (MMP2) level, there was statistically significant difference between (CsA) and (TAC) groups with lower mean in (CsA) group versus (TAC) group. Histopathologically, the degree of tacrolimusinfluenced gingival enlargement was lesser in comparison to (CsA) group.

Conclusions: (CsA) induced a greater degree of gingival enlargement than (TAC) as shown clinically and histolopathologically but the serum level of (MMP2) was higher in (TAC) group than in the (CsA) group. (MMP2) may have a role in the mechanism of gingival enlargement.

KEYWORD: Immunosuppressants, Cyclosporine, Tacrolimus, Drug-induced gingival overgrowth, MMP2

* BDS, Faculty of Dentistry, Mansoura University, Egypt

** Professor of Oral Medicine and Periodontology, Faculty of Dentistry, Mansoura University

*** Professor of Biochemistry Department Faculty of Medicine, Mansoura University

**** Consultant of Nephrology, Mansoura Urology and Nephrology Center, Mansoura University

****** Lecturer of Medical Biochemistry, Faculty of Medicine, Mansoura University

******* Assistant Professor of Oral Biology, Faculty of Dentistry, Mansoura University, Egypt 


\section{INTRODUCTION}

Gingival overgrowth (GO) often develops in patients having renal transplantation and under immune-suppressive therapy, such as Cyclosporine (CsA), which has been widely used from the beginning of the 1970. The rate of gingival enlargement between renal transplant patients who were administered (CsA) is between $13 \%$ to $84.6 \% .^{(1-3)}$ Tacrolimus (TAC) was presented an immunosuppressant drug for the use in organ transplantation in 1987. It could be very good substitute to (CsA). ${ }^{(4)}$ (TAC) has similar side effects in comparison to those of (CsA), but when GO is concerned, the results appear to differ. Many studies linked the occurrence of GO with the use of (TAC) ${ }^{(5)}$ although the growth was at less frequency than with (CsA). ${ }^{(4,6,7)}$ The gingival overgrowth prevalence induced by (TAC) is $14 \% .^{(4,8)}$

The histopathological picture of most of drug induced gingival enlargement is distinguished by increased accumulation of extracellular matrix (ECM) proteins like amorphous ground substance or collagen. ${ }^{(9-11)}$ Variable degrees of inflammatory infiltration exist, however the rise in the number of fibroblasts still debatable. ${ }^{(12,13)}$

Many researches have examined the possible risk factors in the progress of the condition such as duration of renal replacement therapy, dose of (CsA), plaque index ${ }^{(14)}$ and age but still it remains ambiguous why some patients are liable to gingival enlargement, while others remain unaffected. It was reported that drug-associated gingival enlargement casuses a disturbance in the homeostatic equilibrium, which resulted in increased fibroblasts number and the extracellular matrix volume. ${ }^{(14)}$

Matrix metalloproteinases (MMPs) played a major role in the degradation of ECM. (CsA) inhibits the production and activity of (MMP-2) significantly in the serum of the patients undergoing (CsA) treatment. ${ }^{(15)}$ (MMP-2) inhibition may be due to an abnormal accumulation of proteoglycans substrates and glycosaminoglycans, in the (CsA)treated gingival tissue. Consequently, a net reduction in degradative activity existing in (CsA)-treated gingival cells leading to increased collagen content. Very little data are published that focus on (TAC) and gingival enlargement ${ }^{(16)}$, therefore this study was performed to compare gingival overgrowth in (CsA ) versus (TAC) histologically and clinically regarding serum (MMP-2), plaque index, bleeding index, gingival enlargement index, age, duration since transplantation, weight blood, pressure and creatinine level.

\section{MATERIALS AND METHODS}

\section{Patient selection}

This study was done on 54 male patients who were carefully chosen from the urology and nephrology center, Mansoura University. 28 patients under (CsA) immunosuppressive regimen and 26 under (TAC) regimen. Inclusion criteria: Patients who received (CsA) or (TAC) for more than 6 months. Exclusion criteria: Subjects with impaired renal function, patients who used calcium channel blockers, patients who used anticonvulsants (i.e., phenytoin), patients with systemic disorders known to alter gingival tissues like (endocrine diseases, leukemia and thrombocytopenic purpura), any female to avoid any association with sex hormones, edentulous patients and children with erupting teeth.

Study design: Selected cases were divided as follows:

$\mathbf{1}^{\text {st }}$ Group: ( $\left.\mathrm{n}=9\right)$ patients receiving (TAC) and didn't develop gingival enlargement. (were assigned as grade 0 )

$2^{\text {nd }}$ Group: $(\mathrm{n}=6)$ patients receiving $(\mathrm{CsA})$ and didn't develop gingival enlargement (were also assigned as grade 0 ).

$3^{\text {rd }}$ Group: ( $\left.n=17\right)$ patients receiving (TAC) and developed gingival enlargement. This group was divided to two subgroups according to grade of gingival enlargement.

A-Grade $1(n=7)$

B-Grade $2(n=10)$ 
$4^{\text {th }}$ Group: ( $\left.\mathrm{n}=22\right)$ patients receiving $(\mathrm{CsA})$ and developed gingival overgrowth. This group was divided into two subgroups according to grade of gingival enlargement.

A-Grade $1(n=6)$

B-Grade $2(\mathrm{n}=16)$

\section{Medical and Pharmacologic Variables}

Medical and pharmacologic data were reported from each subject's medical records. Data from the last medical attendance were evaluated: age, weight, transplantation date, immunosuppressive drug dose, blood pressure and creatinine level.

\section{Gingival Assessments}

Gingival assessments were accomplished through the papillary bleeding index and plaque index. ${ }^{(17)}$ Gingival overgrowth was assessed in the 6 anterior teeth in upper and lower jaws using gingival overgrowth index as follows ${ }^{(18)}$ Figure $(\mathbf{1}, \mathbf{2}, \mathbf{3})$ :

Grade 0: (No GO with firm adaptation of the attached gingiva to the underlying alveolar bone, there is no increase in density or size of the gingiva)

Grade 1: (Early GO, manifested as rounding of the tip of the papilla, the depth of probing is less than or equal to $3 \mathrm{~mm}$ ).

Grade 2: (Moderate GO, as evidenced by enlarged gingiva with a buccolingual dimension of up to $2 \mathrm{~mm}$, measured from the tip of the papilla outward, the depth of probing is equal to or less than $6 \mathrm{~mm})$.

Grade 3: (Marked GO, the enlarged gingiva has a buccolingual dimension of approximately 3 $\mathrm{mm}$ or more, measured from the tip of the papilla outward, the depth of probing is more than $6 \mathrm{~mm}$ ).

Grade4:(SevereGO,distinguished by a profound thickening of the gingiva, a great percentage of the clinical crown is covered, the probing depth is more than $6 \mathrm{~mm}$ and the buccolingual dimension is approximately $3 \mathrm{~mm}){ }^{(19)}$

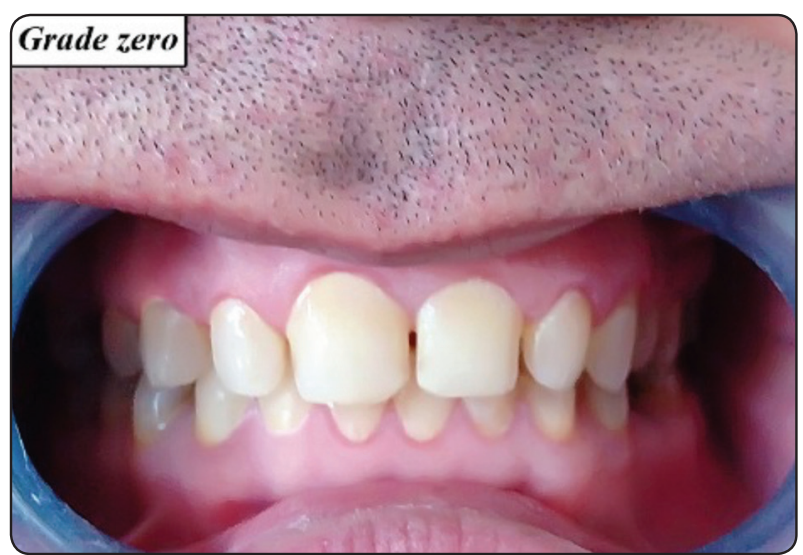

Fig. (1): There is no overgrowth; the attached gingiva is firmly adapted to the underlying alveolar bone. The papilla has a knife edge shape.

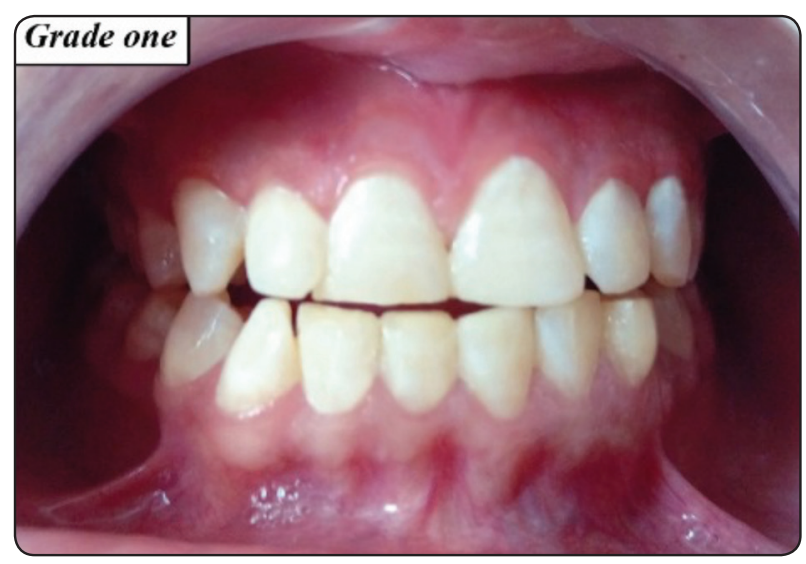

Fig. (2): Early manifestation of overgrowth. Tip of the papilla is round. The depth of probing is said to be less than $3 \mathrm{~mm}$ or equals to $3 \mathrm{~mm}$.

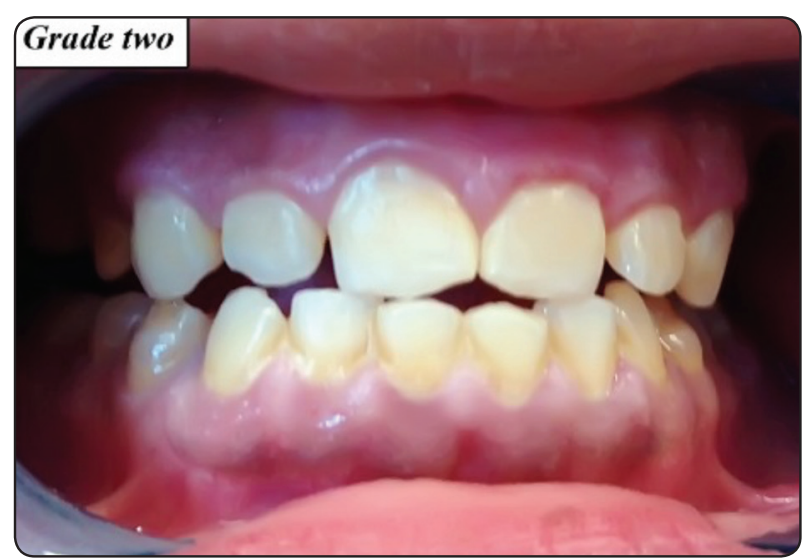

Fig (3): The overgrowth of gingiva is moderate with presence of rolled margins. The buccolingual dimension of gingival enlargement could be of $2 \mathrm{~mm}$. Probing is equal or less than $6 \mathrm{~mm}$. 


\section{Biopsy collection and staining technique}

Informed consents were attained from the patients, tissue biopsies were obtained from interdental area where the tissue conveyed the characteristic signs of gingival enlargement. Localized gingivectomy was performed for the patients of the third group (patients receiving (TAC) and developed gingival overgrowth) and fourth group (patients receiving (CsA) and developed gingival overgrowth), another biopsy was obtained from the retromolar pad or operculum of the transplant patients in order to compare the histopathological pictures of gingival tissues in patients receiving (CsA) with those receiving (TAC) and compare those histologic findings of enlarged gingival tissues to those tissues that didn't reveal gingival enlargement. Specimen were then stained using (H\&E) and immunohistochemistry using caspase 3 expression.

Epithelial thickness was then assessed using Computer Assisted Digital Image Analysis (Digital Morphometric Study) in which the slides were photographed using Olympus ${ }^{\circledR}$ digital camera installed on Olympus ${ }^{\circledR}$ microscope with $1 / 2 \mathrm{X}$ photo adaptor, using $10 \mathrm{X}$ objective. The result images were analyzed on Intel ${ }^{\circledR}$ Core $I 3^{\circledR}$ based computer using Video Test Morphology ${ }^{\circledR}$ software (Russia) with a specific built-in routine for area, count length (Figure 4).

\section{Determination of human Matrix metalloprotein- ase-2 (MMP-2):}

Sera of all groups were collected for determination of (MMP-2) using (MMP-2 ELISA kit (SinoGeneclon, China)) in accordance with the manufacturer`s specifications.

\section{Immunohistochemical, histomorphometric and statistical analysis:}

Caspase 3 immunohistochemical Stain: The slides were incubated for $90 \mathrm{~min}$ with primary antibodies caspase-3 at 1:100 dilution (Thermo Scientific, CA; USA), and then treated for $15 \mathrm{~min}$

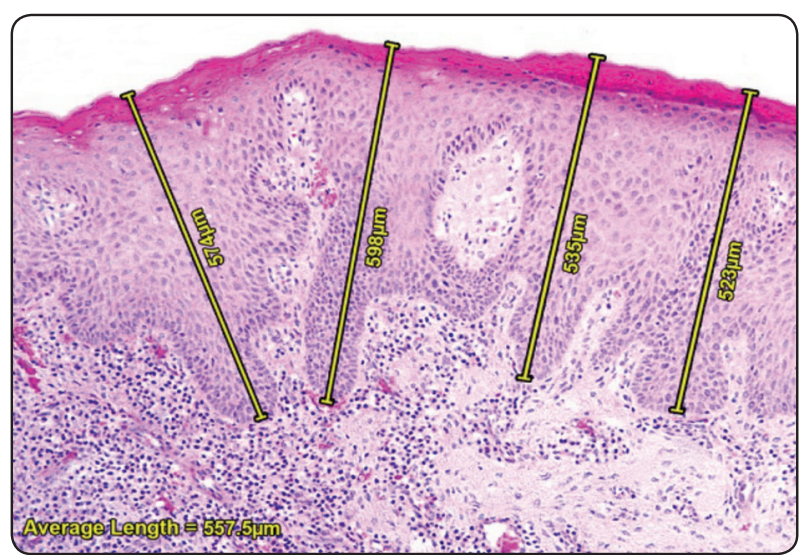

Fig. (4): Photomicrograph of the $4^{\text {th }}$ group, showing the mean value of epithelial thickness after calculating the mean value of the four lengths measured.(H\&E, X100)

with secondary anti-rabbit antibodies. After each treatment, the sections were washed three times with PBS (phosphate buffered solution) for $1 \mathrm{~min}$. The immunostainings were visualized with 3-amino9-ethylcarbazole (AEC) with $5 \mathrm{~min}$ reaction, and counterstained with Mayer's hematoxylin. Negative control was developed by exclusion of the primary antibody. Examining ten fields using thresholding technique was done to measure the intensity of positive immunostaining reaction in all groups to be used in Histomorphometric Analyses. Data were coded, tabulated using Statistical Package for Social Sciencesoftware computer program version 26 (SPSS, Inc., Chicago, IL, USA). ${ }^{(20)}$

\section{RESULTS}

\section{Clinical findings:}

As shown in table 1, 2, 3, there was a positive correlation between the following indices:

1. Plaque index and gingival enlargement index.

2. Plaque index and gingival bleeding index.

3. Creatinine level and plaque index.

There was negative correlation between the following indices:

1. MMP2 and gingival enlargement index.

2. Gingival enlargement index and MMP2. 
TABLE (1) Comparison of studied parameters between (CsA) \& (TAC) groups.

\begin{tabular}{|l|c|c|c|}
\hline & CA & TAC & N=26 \\
\hline & mean \pm SD & mean \pm SD & $<0.001^{*}$ \\
\hline Age (years) & $43.6 \pm 9.31$ & $30.58 \pm 9.99$ & 0.12 \\
\hline Weight (kg) & $76.17 \pm 14.6$ & $69.4 \pm 15.8$ & $<0.001 *$ \\
\hline Duration since transplantation (years) & $15.39 \pm 5.1$ & $5.58 \pm 4.4$ & 0.36 \\
\hline Systolic blood pressure (mmHg) & $126.17 \pm 11.08$ & $123.33 \pm 12.09$ & 0.57 \\
\hline Diastolic blood pressure (mmHg) & $78.62 \pm 6.9$ & $77.41 \pm 9.03$ & $0.017 *$ \\
\hline Index for gingival enlargement & $2.12 \pm 0.62$ & $1.69 \pm 0.64$ & $0.01 *$ \\
\hline Gingival bleeding index & $1.85 \pm 0.5$ & $1.54 \pm 0.4$ & 0.22 \\
\hline Plaque index & $1.89 \pm 0.56$ & $1.71 \pm 0.5$ & 0.49 \\
\hline Creatinine (mg/dL) & $1.24 \pm 0.44$ & $1.16 \pm 0.39$ & $0.047 *$ \\
\hline MMP2 level & $31.78 \pm 14.7$ & $39.56 \pm 13.1$ & \\
\hline
\end{tabular}

*Statistically significant $(p<0.05)$

TABLE (2) Comparison of studied parameters between (CsA) \& (TAC) subgroups.

\begin{tabular}{|c|c|c|c|c|c|c|c|c|}
\hline & \multicolumn{4}{|c|}{ TAC } & \multicolumn{4}{|c|}{ CsA } \\
\hline & $\begin{array}{c}\text { Subgroup } 0 \\
n=9\end{array}$ & $\begin{array}{c}\text { Subgroup } 1 \\
\mathrm{n}=7\end{array}$ & $\begin{array}{c}\text { Subgroup } 2 \\
n=10\end{array}$ & \multirow{2}{*}{$p$} & $\begin{array}{c}\text { Subgroup } 0 \\
n=6\end{array}$ & $\begin{array}{c}\text { Subgroup } 1 \\
n=6\end{array}$ & $\begin{array}{c}\text { Subgroup } 2 \\
n=16\end{array}$ & \multirow{2}{*}{$p$} \\
\hline & mean \pm SD & mean \pm SD & mean $\pm \mathrm{SD}$ & & mean $\pm \mathrm{SD}$ & mean \pm SD & mean \pm SD & \\
\hline Age (years) & $32.0 \pm 11.4$ & $28.7 \pm 11.6$ & $30.6 \pm 8.2$ & 0.82 & $42.0 \pm 3.3$ & $49.0 \pm 14.8$ & $42.25 \pm 8.1$ & 0.29 \\
\hline $\begin{array}{l}\text { Duration since transplantation } \\
\text { (years) }\end{array}$ & $3.56 \pm 1.4$ & $6.0 \pm 2.4$ & $7.1 \pm 2.7$ & 0.26 & $15.3 \pm 5.05$ & $16.67 \pm 5.3$ & $14.9 \pm 4.02$ & 0.7 \\
\hline $\begin{array}{l}\text { Systolic blood pressure } \\
(\mathrm{mmHg})\end{array}$ & $124.4 \pm 10.1$ & $120 \pm 10$ & $125.0 \pm 15.8$ & 0.69 & $120.0 \pm 10.9$ & $124.83 \pm 13.4$ & $128.75 \pm 10.2$ & 0.26 \\
\hline $\begin{array}{l}\text { Diastolic blood pressure } \\
(\mathrm{mmHg})\end{array}$ & $76.7 \pm 7.1$ & $75.7 \pm 11.3$ & $80.0 \pm 9.4$ & 0.59 & $76.7 \pm 8.2$ & $78.33 \pm 7.5$ & $80.0 \pm 6.3$ & 0.59 \\
\hline $\begin{array}{l}\text { Index for gingival } \\
\text { enlargement }\end{array}$ & $1.11 \pm 0.19^{\mathrm{ab}}$ & $1.63 \pm 0.36^{\mathrm{ac}}$ & $2.26 \pm 0.56^{\mathrm{bc}}$ & $<0.001 *$ & $1.39 \pm 0.42^{\mathrm{a}}$ & $1.59 \pm 0.15^{\mathrm{b}}$ & $2.59 \pm 0.29^{\mathrm{ab}}$ & $<0.001 *$ \\
\hline Gingival bleeding index & $1.29 \pm 0.25^{\mathrm{a}}$ & $1.36 \pm 0.16^{\mathrm{b}}$ & $1.89 \pm 0.5^{\mathrm{ab}}$ & $0.002 *$ & $1.76 \pm 0.57$ & $1.48 \pm 0.32^{\mathrm{a}}$ & $2.02 \pm 0.37^{\mathrm{a}}$ & $0.036 *$ \\
\hline Plaque index & $1.45 \pm 0.45^{\mathrm{a}}$ & $1.78 \pm 0.49^{\mathrm{b}}$ & $1.89 \pm 0.63^{\mathrm{ab}}$ & 0.2 & $1.49 \pm 0.42^{\mathrm{a}}$ & $1.56 \pm 0.6^{b}$ & $2.18 \pm 0.43 \mathrm{ab}$ & $0.006^{*}$ \\
\hline Creatinine (mg/dL) & $1.09 \pm 0.3$ & $1.07 \pm 0.3$ & $1.29 \pm 0.5$ & 0.45 & $0.98 \pm 0.23$ & $1.18 \pm 0.23$ & $1.37 \pm 0.52$ & 0.17 \\
\hline MMP2 & $56.16 \pm 2.8^{a b}$ & $36.6 \pm 1.7$ ac & $26.7 \pm 1.6^{b c}$ & $<0.001 *$ & $58.52 \pm 3.5^{\mathrm{ab}}$ & $30.1 \pm 1.47^{\mathrm{ac}}$ & $22.37 \pm 2.8^{\mathrm{bc}}$ & $<0.001 *$ \\
\hline Drug level & $6.36 \pm 2.07$ & $7.5 \pm 1.37$ & $5.63 \pm 4.5$ & 0.64 & $85.8 \pm 49.3$ & $65.0 \pm 22.1$ & $90.14 \pm 32.8$ & 0.34 \\
\hline
\end{tabular}


TABLE (3). Correlation matrix between (CsA) \& (TAC) dose and indices measured among (CsA) and (TAC) cases.

\begin{tabular}{|c|c|c|c|c|c|c|c|}
\hline \multirow{2}{*}{\multicolumn{2}{|c|}{ CsA dose }} & \multicolumn{3}{|c|}{ CSA cases } & \multicolumn{3}{|c|}{ TAC cases } \\
\hline & & \multirow{2}{*}{$\frac{\text { MMP- } 2}{0.259}$} & \multirow{2}{*}{$\begin{array}{c}\text { Drug level } \\
-0.729\end{array}$} & \multirow{2}{*}{$\frac{\text { TAC dose }}{0.063}$} & \multirow{2}{*}{$\begin{array}{c}\text { MMP2 } \\
0.034\end{array}$} & \multirow{2}{*}{$\begin{array}{c}\text { Drug level } \\
-0.746\end{array}$} & \multirow[b]{2}{*}{0.208} \\
\hline Index for gingival & $\mathbf{r}$ & & & & & & \\
\hline enlargement & $\mathbf{p}$ & 0.175 & $<0.001$ & 0.761 & 0.870 & $<0.001$ & 0.379 \\
\hline \multirow{2}{*}{ Gingival bleeding } & $\mathbf{r}$ & 0.111 & -0.175 & -0.073 & -0.296 & -0.539 & 0.199 \\
\hline & $\mathbf{p}$ & 0.565 & 0.363 & 0.722 & 0.142 & 0.004 & 0.401 \\
\hline \multirow{2}{*}{ Plaque index } & $\mathbf{r}$ & 0.233 & -0.503 & 0.173 & -0.263 & -0.340 & 0.269 \\
\hline & $\mathbf{p}$ & 0.223 & 0.005 & 0.398 & 0.195 & 0.083 & 0.252 \\
\hline \multirow{2}{*}{ Creatinine } & $\mathbf{r}$ & 0.283 & -0.353 & 0.108 & 0.373 & -0.212 & -0.180 \\
\hline & p & 0.144 & 0.066 & 0.600 & 0.066 & 0.300 & 0.449 \\
\hline \multirow{2}{*}{ SBP } & $\mathbf{r}$ & -0.004 & -0.295 & -0.114 & 0.329 & -0.020 & -0.300 \\
\hline & p & 0.984 & 0.121 & 0.579 & 0.101 & 0.922 & 0.199 \\
\hline \multirow{2}{*}{ DBP } & $\mathbf{r}$ & 0.168 & -0.090 & -0.008 & 0.186 & -0.141 & -0.274 \\
\hline & p & 0.385 & 0.641 & 0.970 & 0.364 & 0.483 & 0.242 \\
\hline \multirow{2}{*}{ MMP2 } & $\mathbf{r}$ & -0.199 & - & -0.061 & -0.005 & - & 0.076 \\
\hline & p & 0.301 & - & 0.766 & 0.979 & - & 0.750 \\
\hline \multirow{2}{*}{ Drug level } & $\mathbf{r}$ & 0.702 & -0.061 & - & -0.152 & 0.076 & - \\
\hline & $\mathrm{p}$ & $<0.001$ & 0.766 & - & 0.534 & 0.750 & - \\
\hline
\end{tabular}

R: Pearson correlation coefficient P: probability

\section{Histopathological findings:}

\section{1- Hematoxylin and eosin (H\&E) stain results:}

\section{$I^{\text {st }}$ Group patients receiving $($ TAC) and didn't} $\operatorname{develop}(\mathrm{GO})$

The gingival tissues of this group showed thick epithelium with short and narrow retepegs. Granular cell layer consisted of flattened cells. There was an increase in keratin layer. While the connective tissue showed regular collagen fibers, few vascular channels and small number of inflammatory cells. Figure (5 A)

\section{$2^{\text {nd }}$ Group patients receiving $(C s A)$ and didn't develop $(G O)$}

Retepegs were broader and taller than that of the first group. The gingival tissues showed thick
* Statistically significant $(P<0.05)$

epithelium. The basal cells had a deeply stained oval nucleus and were perpendicularity arranged to basement membrane. The prickle cell layer showed acanthosis with a faintly stained nucleus. The stratum granulosum consisted of flattened cells that were deeply stained with basic dyes. The keratin layer was thicker than the first group and quite adherent to the underlying layer. The connective tissue showed regular arrangement of collagen fibers and blood vessels but increased collagen fibers and inflammatory cells than the first group. Figure (5 B)

\section{$3^{r d}$ Group patients receiving (TAC) and devel- oped $(G O)$}

Retepegs were longer and deeper than the $2^{\text {nd }}$ group. The basal cell layer showed crowding. 
There was acanthosis in the prickle cell layer and the keratin layer showed more hyperkeratosis. The vascular channels were prominent and chronic inflammatory cells were present. Figure (5 C)

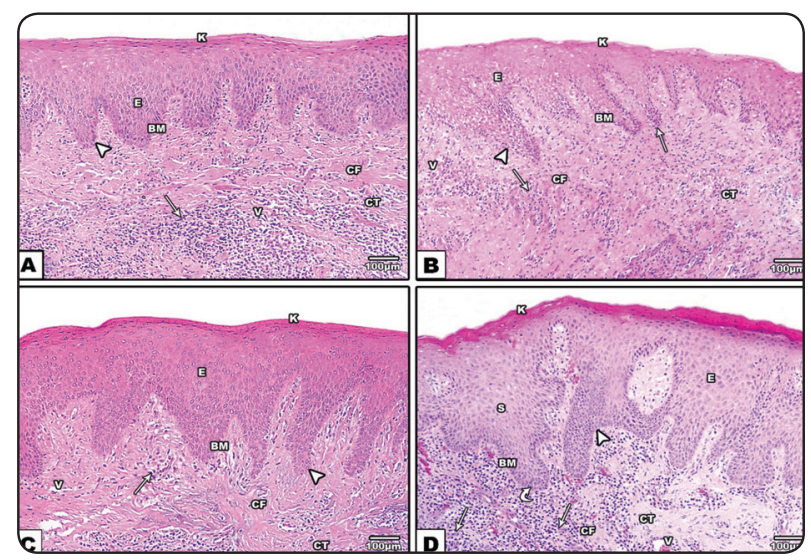

Fig. (5)(A) photomicrograph of $1^{\text {st }}$ group, showing keratinized stratified squamous epithelium (E) covering a core of connetive tissue (CT). The basement membrane (BM) with short and narrow rete process (arrow head). Underlying connective tissue with few vascular channels (V) and showing coarse collagen fibers (CF) with presence of inflammatory cells (arrow). (B) photomicrograph of $2^{\text {nd }}$ group showing hyperkeratinized stratified squamous epithelium (E) covering a core of connetive tissue (CT), basal cells are deeply stained, the basement membrane $(\mathrm{BM})$ with elongated rete process (arrow head). Underlying connective tissue with more vascular channels (V) and increased collagen fibers (CF) and inflammatory cells (arrow). (C) photomicrograph of $3^{\text {rd }}$ group showing hyperkeratinized stratified squamous epithelium with increase thickness of keratin (E) covering a core of connetive tissue (CT), basal cells show crowding, the basement membrane (BM) with elongated rete process (arrow head). Underlying connective tissue with more frequent vascular channels $(\mathrm{V})$ and increase collagen fibers (CF) and of inflammatory cells (arrow) than $2^{\text {nd }}$ group. (D) photomicrograph of $4^{\text {th }}$ group showing hyperkeratinized stratified squamous epithelium with increased thickness of keratin (E) with more acanthosis (S) covering a core of connetive tissue (CT), basal cells show crowding (curved arrow), the basement membrane (BM) with elongated broad and large rete process (arrow head). Underlying connective tissue with more frequent vascular channels (V) and increase collagen fibers (CF) and inflammatory cells (arrow) than 3rd group.(H\&E X100)

\section{$4^{\text {th }}$ Group patients receiving (CsA) and devel- oped $(G O)$}

This group showed marked increase in epithelial thickness. Retepegs were broad, elongated, irregular and penetrating deeply into underlying connective tissue forming a network appearance. The cytological changes within the cells of the epithelial layers were more obvious than all other groups. The basal cell layer showed marked crowding and the keratin layer showed more parakeratinization than the $3^{\text {rd }}$ group. The spinous cell layer exhibited noticeable acanthosis. The connective tissue underneath showed collagen fibers which were densely and coarsely dispersed with greater number inflammatory cell infiltrate. Figure (5 D)

The bar chart Figure (6) compares the mean epithelial thickness among all the studied groups, with the mean of the lowest value in the first group and the mean of the highest value in the fourth group.

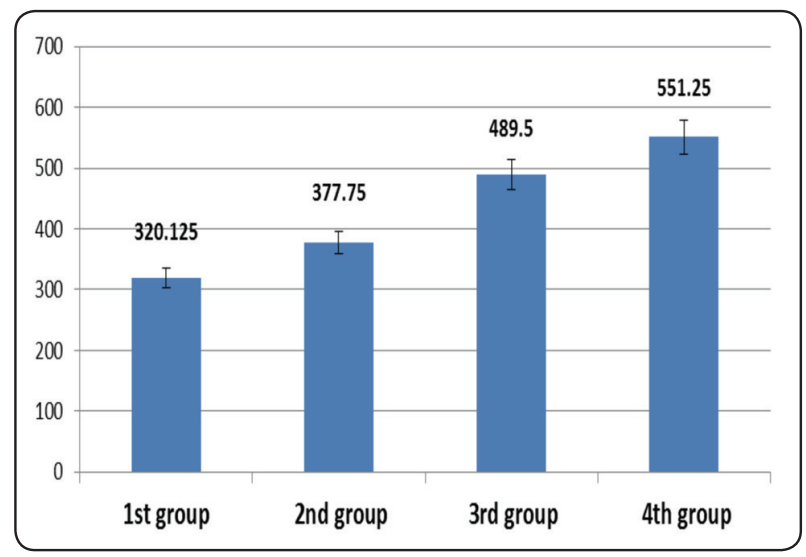

Fig. (6): Bar chart for epithelial thickness mean values for all groups

\section{2- Immunohistochemistry and histomorphomet- ric Analyses.}

By using caspase 3 expression, specimens stained with caspase- 3 antigen are shown in Figure (7). $1^{\text {st }}$ group showed hyperplastic epithelium with nuclear brown staining of keratinocytes revealing the apoptosis of cells in this group. The number of apoptotic cells and caspase-3 levels were significantly lesser in the $2^{\text {nd }}, 3^{\text {rd }}$ and $4^{\text {th }}$ groups compared to the $1^{\text {st }}$ group as shown in Figure (8). 


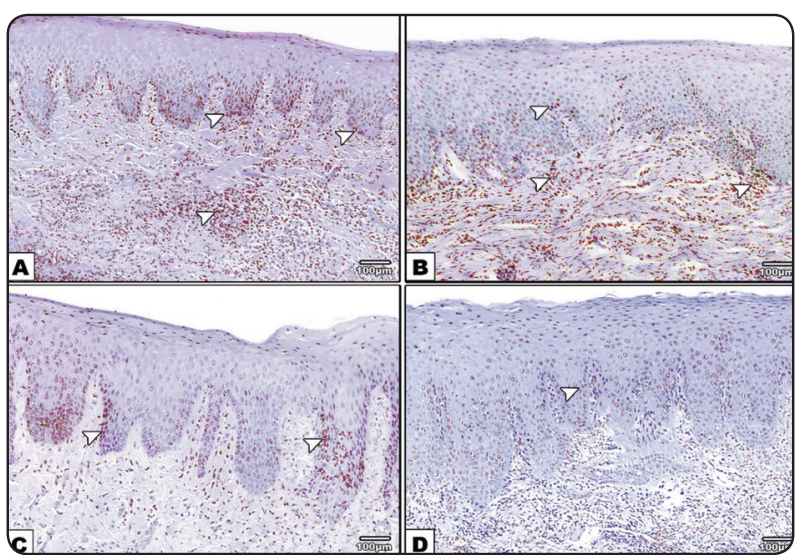

Fig. (7) (A) Photomicrograph of $1^{\text {st }}$ group, showing cytoplasmic caspase-3 staining (arrow heads) was detected throughout the hyperplastic epithelium. (B) Photomicrograph of $2^{\text {nd }}$ group showing epithelial cells of the basal layers with cytoplasmic staining (arrow heads) of caspase- 3 . (C) Photomicrograph of $3^{\text {rd }}$ group showing keratinocytes in the hyperplastic epithelium with nuclear staining (arrow heads). (D) Photomicrograph of $4^{\text {th }}$ group showing reaction of the epithelial cells of the basal layer (arrow head). (Caspase-3 immunostaining; X100)

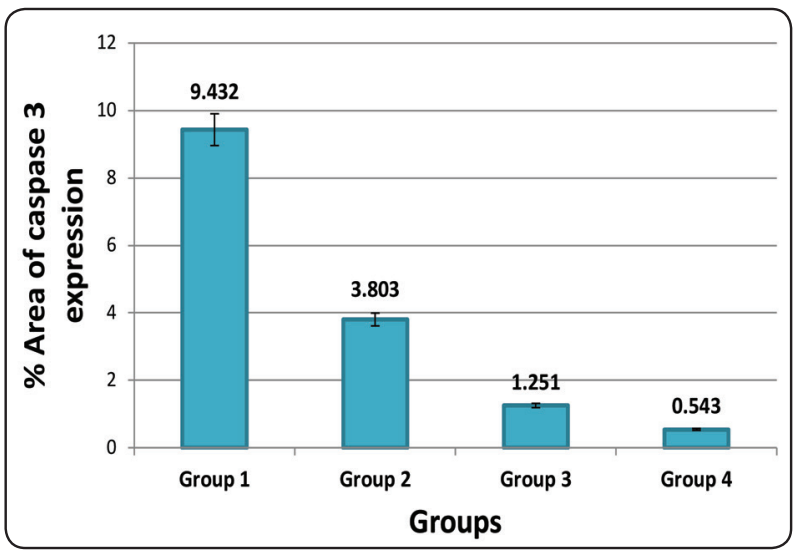

Fig. (8) Bar chart of \% Area of caspase 3 expression distribution in the four studied groups.

\section{DISCUSSION}

In this study there was a positive relation between gingival enlargement index and gingival bleeding index among (CsA) cases and also a positive relation between gingival enlargement index and gingival bleeding index among (TAC) cases. This could be attributed to the tendency of (TAC) to cause thrombocytopenia more than (CsA) (21), this is in accordance with Alkhateeb et al (21) who stated that (TAC) is said to cause immune thrombocytopenia and that switching from (TAC) to (CsA) in all their patients led to an increase in platelet count within 6 days to 2 months ${ }^{(22)}$, this is in accordance with Woytowitz et al, who showed that (TAC) seems to infrequently result in a refractory immune thrombocytopenia an unusual side effect with termination of the drug usage. ${ }^{(23)}$

In this study, there was a positive correlation between creatinine level and plaque index in (CsA) group. This could be explained as when the creatinine levels increase this may be an indicator of decreased kidney function which results in a drop in phosphate excretion and this lead to increased levels of serum phosphorus, excess phosphorus causes serum calcium to be deposited ${ }^{(24)}$, and as a result, higher plaque and calculus deposition. ${ }^{(25)}$

In the present study there was a significant difference between (CsA) and (TAC) group concerning MMP2 serum level with higher mean in (TAC) group than in (CsA) group. (TAC) seems to induce a greater increase in expression of (MMP2) when compared to (CsA) this is in accordance with some studies that have shown that (CsA) could cause inhibition in the production of (MMP-2) in gingival fibroblasts, ${ }^{(26,27)}$ this is in accordance with Kuo et al ${ }^{(28)}$ Bolzani et al ${ }^{(15)}$, Cotrim et al ${ }^{(29)}$ and Fornoni et $\mathrm{al}^{(30)}$ while it is in contrast with Gagliano et al who stated that (CsA) treatment has no effect on (MMP-2 mRNA ) and protein levels. ${ }^{(31)}$

It is proposed that in vitro (TAC) significantly raised the protein expression and the gene of (MMP-1) and the level of MMP-2 mRNA ${ }^{(32)}$ this 
is in contrast with Gagliano et al, who discovered that FK506 did not affect the fibroblasts. ${ }^{(33)}$ Jain et al also showed that the expression of MMP2 was not raised by (TAC) therapy however (CsA) therapy reduced expression of (MMP2). ${ }^{(34)}$ Bicknell et al found evidence that (TAC) may have less fibrogenic effect than (CsA) ${ }^{(35)}$ Gagliano et al discovered that FK506 did not alter the fibroblasts' morphology. Furthermore, the drug caused less proliferation of fibroblast at the three intervals tests. ${ }^{(33)}$

In this study the $4^{\text {th }}$ group patients receiving (CsA) and developed gingival overgrowth showed marked increase in epithelial thickness, broad, elongated, irregular rete pegs and penetrating deeply into underlying connective tissue forming a network appearance. The connective tissue revealed collagen bundles that are thick and coarse with dense inflammatory cell infiltrate.

This is in accordance to abouelkheir et $\mathrm{al}^{(36)}$, goncllave et $\mathrm{al}^{(37)}$ Carranza et al and Seibel et $\mathrm{al}^{(38)}$ who reported that thickening of epithelium and elongated rete processes appear to be a characteristic feature of (CsA) induced (GO) this is also in accordance with Schincaglia et $\mathrm{l}^{(39)}$ who stated that (CsA) stimulates collagen synthesis. Tipton et al ${ }^{(40)}$ and Sugano et al ${ }^{(41)}$ who showed that (CsA) treatment down regulates collagenase mRNA expression by human gingival fibroblasts in vitro.

This is in contrast with other authors Willershausen-Zönnchen et al ${ }^{(42)}$ and James et al ${ }^{(43)}$ who studied the influence of (CsA) on type I collagen synthesis in human gingival fibroblasts and claimed (CsA) didn't inhibit or had any effect on collagen synthesis.

In this study the $3^{\text {rd }}$ group patients receiving (TAC) and developed gingival overgrowth showed rete process that are long and deep. The basal cell layer showed crowding. There was acanthosis in prickle cell layer. The keratin layer showed hyperkeratosis but less than the enlarged (CsA) group. The underlying connective tissue revealed dense collagen fibers. The cytological changes within the cells of the epithelial layers were more obvious in (CsA) group than those of groups received (TAC). This is in accordance with Prabhu et al who suggested that the degree of tacrolimus-influenced gingival enlargement seems to be lesser in comparison to (CsA). ${ }^{(43)}$ With regards to caspase-3 levels, the number of apoptotic cells and caspase-3 levels were significantly lesser in the $2^{\text {nd }}, 3^{\text {rd }}$ and $4^{\text {th }}$ groups compared to the $1^{\text {st }}$ group and this is in agreement with Mitic K et al ${ }^{(44)}$ who reported that the keratinocyte apoptosis expression and the decreased level of caspase- 3 may have a great role in the gingivae of kidney transplant patients receiving (CsA).

Kantarci et al, noted that in gingival overgrowth, fibroblast apoptosis is decreased, and that this decrease may be related to fibrosis and highest proportion of fibroblastic cells and connective tissue fibers. ${ }^{(45)}$ Further studies are needed in this regard, as very little published data exist that focus on (TAC) and gingival enlargement.

\section{Advantages of the current study}

- Exclusion of patients receiving other drugs causing drug induced gingival overgrowth (DIGO) only (CsA) and (TAC).

- Excluding female and young patients.

- The first human study that studied the histopathological picture of gingival enlargement regarding (TAC) treated patients.

- The study was performed among Egyptian population on live donors.

\section{CONCLUSIONS}

- (CsA) causes more gingival enlargement than (TAC) regarding different clinical indexes and evidenced histologically and through measurement of serum MMP2 analysis.

- (TAC) causes more bleeding tendency than (CsA). 
- Increase in creatinine level is related to increasing the plaque index through increased calcium deposition.

- (MMP2) has a high inverse relation to gingival enlargement.

\section{RECOMMENDATIONS}

- In (CsA) cases that exhibit gingival enlargement switching to (TAC) is advisable.

- Measures taken to improve kidney function and creatinine level could decrease the probability of $(\mathrm{GO})$.

- Reaching drugs that could increase the (MMP2) level and improve gingival enlargement.

\section{REFERENCES}

1. Somacarrera ML, Hernandez G, Acero J, Moskow BS. (1994) Factors related to the incidence and severity of cyclosporin-induced gingival overgrowth in transplant patients. A longitudinal study. Journal of periodontology ;65(7):671-5.

2. Margiotta V, Pizzo I, Pizzo G, Barbaro A. (1996) Cyclosporin- and nifedipine-induced gingival overgrowth in renal transplant patients: correlations with periodontal and pharmacological parameters, and HLA-antigens. Journal of oral pathology \& medicine : official publication of the International Association of Oral Pathologists and the American Academy of Oral Pathology ;25(3):128-34.

3. Afonso M, Bello Vde O, Shibli JA, Sposto MR. (2003) Cyclosporin A-induced gingival overgrowth in renal transplant patients. Journal of periodontology ;74(1):51-6.

4. Ellis JS, Seymour RA, Taylor JJ, Thomason JM. (2004) Prevalence of gingival overgrowth in transplant patients immunosuppressed with tacrolimus. Journal of clinical periodontology ;31(2):126-31.

5. Adams CK, Famili P. (1991) A study of the effects of the drug FK 506 on gingival tissues. Transplantation proceedings ;23(6):3193-4.

6. Shapiro R, Jordan M, Scantlebury V, Vivas C, Fung J, McCauley J, et al. (1994) A prospective, randomized trial of FK-506 in renal transplantation-A comparison between double-and triple-drug therapy. Clinical transplantation ;8(6):508
7. Sekiguchi RT, Paixão CG, Saraiva L, Romito GA, Pannuti CM, Lotufo RFM. (2007) Incidence of tacrolimusinduced gingival overgrowth in the absence of calcium channel blockers: a short-term study. Journal of clinical periodontology ;34(7):545-50.

8. Greenberg KV, Armitage GC, Shiboski CH. (2008) Gingival enlargement among renal transplant recipients in the era of new-generation immunosuppressants. Journal of periodontology ;79(3):453-60.

9. Marshall RI, Bartold PM. (1999) A clinical review of druginduced gingival overgrowths. Australian dental journal ;44(4):219-32.

10. Dongari A, McDonnell HT, Langlais RP. (1993) Druginduced gingival overgrowth. Oral surgery, oral medicine, and oral pathology ;76(4):543-8.

11. Hallmon WW, Rossmann JA. (2000. 1999) The role of drugs in the pathogenesis of gingival overgrowth. A collective review of current concepts. Periodontology ;21:176-96.

12. Wysocki GP, Gretzinger HA, Laupacis A, Ulan RA, Stiller CR. (1983) Fibrous hyperplasia of the gingiva: a side effect of cyclosporin A therapy. Oral surgery, oral medicine, and oral pathology ;55(3):274-8.

13. Santi E, Bral M.(1998) Effect of treatment on cyclosporineand nifedipine-induced gingival enlargement: clinical and histologic results. The International journal of periodontics $\&$ restorative dentistry ;18(1):80-5.

14. Kurzawski M, Drozdzik A, Dembowska E, Pawlik A, Banach J, Drozdzik M. (2006) Matrix metalloproteinase-1 gene polymorphism in renal transplant patients with and without gingival enlargement. Journal of periodontology ;77(9):1498-502.

15. Bolzani G, Coletta RD, Júnior HM, De Almeida OP, Graner E. (2000) Cyclosporin A inhibits production and activity of matrix metalloproteinases by gingival fibroblasts. Journal of periodontal research ;35(1):51-8.

16. Prabhu A, Mehta DS. (2006) A morphologic comparison of gingival changes influenced by cyclosporin and tacrolimus in rats: an experimental study. Journal of periodontology ;77(2):265-70.

17. Loe H, Silness J. (1963) Periodontal disease in pregnancy.I. Prevalence and severity. Acta odontologica Scandinavica ;21:533-51.

18. Ingles E, Rossmann JA, Caffesse RG. (1999) New clinical index for drug-induced gingival overgrowth. Quintessence international (Berlin, Germany : 1985) ;30(7):467-73. 
19. Giusto TJ. (2005) Periodontal management of gingival overgrowth in a renal transplant patient: a case report. J N J Dent Assoc ;76(2):26-9.

20. Topdag M, Topdag DO, Ila K, Muezzinoglu B, Yaprak B, Ozturk M, et al. (2014) The effect of memantine on functional recovery of the facial nerve after crush injury. Eur Arch Oto-Rhino-Laryngology ;272:473-8.

21. Arai K, Kuramitsu K, Fukumoto T, Kido M, Takebe A, Tanaka M, et al. (2016) A Case Report of Drug-Induced Thrombocytopenia after Living Donor Liver Transplantation. The Kobe Journal of Medical Sciences ;62(1):9-12

22. Alkhateeb H, Manchanda N, Mehta RP. (2010) Tacrolimus Induced Refractory Immune Thrombocytopenia. Blood ;116(21):1426.

23. Woytowitz D, Smith RE, Mehta RP. (2013) TacrolimusInduced Refractory Immune Thrombocytopenia In Solid Organ Transplant Patients. Blood ;122(21):2317.

24. Wesseling-Perry K. (2010) FGF-23 in bone biology. Pediatric Nephrology ;25(4):603-8.

25. Proctor R, Kumar N, Stein A, Moles D, Porter S. (2005) Oral and dental aspects of chronic renal failure. Journal of dental research ;84(3):199-208.

26. Abe M, Yokoyama Y, Syuto T, Ishibuchi H, Ishikawa O. (2008) Interleukin-6 counteracts effects of cyclosporin A on extracellular matrix metabolism by human dermal fibroblasts. Cell and tissue research ;333(2):281.

27. Chiu HC, Lu YT, Chin YT, Tu HP, Chiang CY, Gau CH, et al. (2009) Cyclosporine A inhibits the expression of membrane type-I matrix metalloproteinase in gingiva. J Periodontal Res ;44(3):338-47.

28. Kuo PJ, Tu HP, Chin YT, Lu SH, Chiang CY, Chen RY, et al. (2012) Cyclosporine-A inhibits MMP-2 and-9 activities in the presence of Porphyromonas gingivalis lipopolysaccharide: an experiment in human gingival fibroblast and U937 macrophage co-culture. Journal of periodontal research ;47(4):431-8.

29. Cotrim P, de Andrade CR, Martelli-Junior H, Graner E, Sauk JJ, Coletta RD. (2002) Expression of matrix metalloproteinases in cyclosporin-treated gingival fibroblasts is regulated by transforming growth factor (TGF)-beta1 autocrine stimulation. Journal of periodontology ;73(11):131322.

30. Fornoni A, Lenz O, Tack I, Potier M, Elliot SJ, Striker LJ, et al. (2000) Matrix accumulation in mesangial cells exposed to cyclosporine A requires a permissive genetic background. Transplantation ;70(4):587-93.
31. Gagliano N, Moscheni C, Dellavia C, Torri C, Stabellini G, Ferrario VF, et al. (2004) Effect of cyclosporin A on human gingival fibroblast collagen turnover in relation to the development of gingival overgrowth: an in vitro study. Biomedicine \& pharmacotherapy = Biomedecine \& pharmacotherapie ;58(4):231-8.

32. Gagliano N, Moscheni C, Torri C, Dellavia C, Stabellini G, Ferrario VF, et al. (2005) Differential effect of cyclosporin A and FK506 on SPARC mRNA expression by human gingival fibroblasts. Biomedicine \& pharmacotherapy ;59(5):249-52.

33. Gagliano N, Moscheni C, Dellavia C, Stabellini G, Ferrario VF, Gioia M. (2005) Immunosuppression and gingival overgrowth: gene and protein expression profiles of collagen turnover in FK506-treated human gingival fibroblasts. Journal of clinical periodontology ;32(2):167-73.

34. Jain S, Bicknell GR, Nicholson ML. (2000) Tacrolimus has less fibrogenic potential than cyclosporin A in a model of renal ischaemia-reperfusion injury. The British journal of surgery ;87(11):1563-8.

35. Bicknell G, Williams S, Shaw J, Pringle J, Furness P, Nicholson M. (2000) Differential effects of cyclosporin and tacrolimus on the expression of fibrosis-associated genes in isolated glomeruli from renal transplants. BJS ;87(11):1569-75.

36. Elkhier MA, EL-Zehary R, Mourad M, El-Khier NA. (2014) Immunohistochemical assessment of Bcl-2 and Ki67 in gingival tissues of normal and immunosuppressed patients as predictors of neoplasia. Annals of Oral \& Maxillofacial Surgery ;2(2):14.

37. Goncalves SC, Diaz-Serrano KV, de Queiroz AM, Palioto DB, Faria G. (2008) Gingival overgrowth in a renal transplant recipient using cyclosporine A. Journal of dentistry for children (Chicago, Ill) ;75(3):313-7.

38. Seibel W, Yahia NA, McCleary LB, Lesko LJ, Hassell TM. (1989) Cyclosporine-induced gingival overgrowth in beagle dogs. Journal of oral pathology \& medicine : official publication of the International Association of Oral Pathologists and the American Academy of Oral Pathology;18(4):240-5.

39. Schincaglia G, Forniti F, Cavallini R, Piva R, Calura G, Senno L. (1992) Cyclosporin-A increases type I procollagen production and mRNA level in human gingival fibroblasts in vitro. Journal of oral pathology \& medicine ;21(4):181-5.

40. Tipton DA, Stricklin GP, Dabbous MK. (1991) Fibroblast heterogeneity in collagenolytic response to cyclosporine. Journal of cellular biochemistry ;46(2):152-65. 
41. Sugano N, Ito K, Murai S. (1998) Cyclosporin A inhibits collagenase gene expression via AP-1 and JNK suppression in human gingival fibroblasts. J Periodontal Res ;33(8):448-52.

42. Willershausen-Zönnchen B, Lemmen C, Schumacher U. (1992) Influence of cyclosporine A on growth and extracellular matrix synthesis of human fibroblasts. Journal of cellular physiology ;152(2):397-402.

43. James JA, Irwin CR, Linden GJ. (1995) The effects of culture environment on the response of human gingival fibroblasts to cyclosporin A. Journal of periodontology; 66(5):339-44.

44. Mitic K, Popovska M, Pandilova M, Jovanovic R, Spasovski G, Nikolov V. (2013) The role of inflammation and apoptosis in cyclosporine A-induced gingival overgrowth. Bosn J Basic Med Sci ;13(1):14-20.

45. Kantarci A, Augustin P, Firatli E, Sheff CM, Hasturk H, Graves TD, Trackman CP. (2007) Apoptosis in Gingival Overgrowth Tissues. J Dent Res ; 86(9): 888-892. 